\title{
IMPROVING UNSUSTAINABLE ENVIRONMENTAL GOVERNANCE IN SOUTH AFRICA: THE CASE FOR HOLISTIC GOVERNANCE
}

LJ Kotzé*

\section{Introduction}

Environmental governance in the $21^{\text {st }}$ century in South Africa faces serious challenges in terms of improving service-delivery. ${ }^{1}$ Despite the progressive domestic environmental law framework, fragmentation of the environmental governance effort is a reality in South Africa. ${ }^{2}$ Fragmentation presents itself in terms of structural fragmentation between the various spheres of government and the various line functionaries in each sphere. Environmental statutes are also fragmented, since the legislative framework consists of a multitude of acts which are silo-based and environmental-media specific. This is especially observed in terms of the various environmental authorisation procedures that are prescribed by the legal framework. ${ }^{3}$ This matrix framework of fragmented legislation further gives rise to duplication of administrative procedures, jurisdictional overlap, and a time-consuming and confusing governance effort. This may lead to an untenable situation since section 24 of the Constitution of the Republic of South Africa, 1996 (hereafter the 1996 Constitution), and the

* B Com (Law), LLB, LLM (PUCHE), LLD (NWU); Senior Lecturer, Faculty of Law, North West University; Potchefstroom Campus. This article is based on a paper presented at the Annual Conference of the International Association of Impact Assessment/ Environmental Law Association of South Africa, Thaba' Nchu, August 2005. My sincere thanks to Willemien du Plessis for her helpful comments on an earlier version of this article. The views expressed herein and any errors are my own.

1 It has, for example, been reported that the cost of red tape in South Africa amounted to an estimated R79 billion in 2004 (costs incurred by the business sector as a result of inefficient governmental regulation). Environmental governance is part of the whole governance effort, and is necessarily included in this estimation. See in this regard SPG Counting the Cost.

2 For a comprehensive discussion on fragmentation of the South African environmental law regime, see CEM Report 1-374; and Kotzé Legal Framework 2-335.

3 See, for example, Wessels Environmental Authorisations for a discussion on fragmented mining authorisations. 
environmental law order in general, endorses the concept of sustainability. ${ }^{4}$ The central hypothesis of this article is that fragmentation may inhibit and negate sustainable environmental governance efforts, especially insofar as it may lead to unsustainable service-delivery by environmental departments. Sustainable environmental governance should be understood in terms of the concept of sustainability which is defined as:

The ability to maintain a desired condition over time without eroding natural, social and financial resource bases, through a process of continual improvement in the form of sustainable development. Sustainability also relates to the integration of various considerations, including: the environment, the economy, social factors, environmental governance and management efforts, and public and industry involvement. Sustainability results may be achieved through application and implementation of the various principles of sustainability. ${ }^{5}$

Addressing fragmentation may thus arguably be one of the most contentious issues to be considered in future environmental law and governance reforms. This article argues that fragmentation of the environmental governance effort leads to unsustainable results in terms of effective and adequate servicedelivery by government. Integration, or a form of holistic environmental governance, may contribute to direct reform initiatives on a sustainable path. The article commences with an exposition on fragmentation. The concept of integrated or holistic governance is discussed, and recommendations are made on some strategies that may be employed to achieve holistic environmental governance. These strategies include: a one-stop environmental governance

4 S 24 states that:

Everyone has the right -

(a) to an environment that is not harmful to their health or well-being; and

(b) to have the environment protected, for the benefit of present and future generations, through reasonable legislative and other measures that -

(i) prevent pollution and ecological degradation;

(ii) promote conservation; and

(iii) secure ecologically sustainable development and use of natural resources while promoting justifiable economic and social development.

5 Kotzé Legal Framework 20. The principles of sustainability include, amongst others, the polluter pays principle, the duty of care principle, the principle of continual improvement, the preventive approach, an integrated and holistic approach, and the precautionary approach. 
shop; integrated pollution prevention and control (hereafter IPPC); and cooperative environmental governance (hereafter CEG).

\section{$2 \quad$ Fragmentation}

\section{$2.1 \quad$ Nature and extent}

\subsubsection{Institutional fragmentation}

A comprehensive survey of fragmented environmental governance efforts in South Africa suggests that fragmentation manifests in various ways. ${ }^{6}$ Firstly, one may speak of vertical and horizontal fragmentation of the environmental governance structure (institutional framework). Vertical fragmentation refers to the three separate and autonomous spheres of government, namely the national, provincial and local spheres. In each sphere, various independent and autonomous environmental departments, or line functionaries, exist. These line functionaries include, amongst others, the Department of Environmental Affairs and Tourism (hereafter DEAT); the Department of Water Affairs and Forestry (hereafter DWAF); the Department of Minerals and Energy (hereafter DME), the Department of Agriculture, and the South African Heritage Resource Agency. The institutional framework relating to environmental governance is thus fragmented in both a horizontal and vertical sense. ${ }^{7}$

\subsubsection{Legislative fragmentation}

Secondly, the framework of environmental legislation in South Africa is fragmented. Fragmentation of legislation may be divided into vertical; horizontal (which is not to be confused with vertical and horizontal fragmentation of the institutional framework); framework/sectoral; and inter-sectoral fragmentation. These manifestations of fragmentation are discussed hereafter.

6 CEM Report 1-374.

7 See also Besdziek Provincial Government 191 on horizontal and vertical fragmentation. 


\subsubsection{Vertical fragmentation}

Legislation is in some instances fragmented in a vertical sense. The legislative framework relating to biodiversity serves as an example. Firstly, there is the National Environmental Management: Biodiversity Act 10 of 2004 which is the primary act relating to biodiversity, as well as various other acts which may have a direct or indirect influence on biodiversity conservation. ${ }^{8}$ These acts operate in the national sphere. The relevant Member of the Executive Council (hereafter MEC) may however publish in the Provincial Government Gazette various provisions which will essentially operate in the provincial sphere. These include, for example, section 52(1) which empowers the MEC to publish a provincial list of ecosystems that are threatened and in need of protection; and section 70 which empowers the MEC to publish a provincial list of invasive species for a particular province in concurrence with the Minister.

Apart from provincial regulations there is also a plethora of provincial ordinances and acts which may be applicable to biodiversity conservation in the provincial sphere. These include, amongst others: the Nature and Environmental Conservation Ordinance 19 of 1974, the Mpumalanga Nature Conservation Act 10 of 1998, the Limpopo Environmental Management Act 7 of 2003, the Nature Conservation Ordinance 12 of 1983 (former Transvaal), the Nature Conservation Ordinance 8 of 1969 (former Orange Free State), and the Western Cape Nature Conservation Laws Amendment Act 2000. In the local sphere, fragmented planning frameworks for regulating biodiversity exist together with the national laws of relevance to biodiversity which all prescribe national development planning frameworks. These need to be reconciled with provincial and local spatial planning frameworks such as Spatial Development Frameworks, Integrated Development Plans, zoning schemes and policy other frameworks relating to biodiversity. This clearly illustrates vertical fragmentation

8 See par 2.1.2.2 below for a discussion on horizontal fragmentation of biodiversity legislation. 
of legislation along the national, provincial and local spheres of government, which relate to a single aspect, namely biodiversity.

\subsubsection{Horizontal fragmentation}

Horizontal fragmentation is evident from the various sectoral, or silo-based environmental acts that exist. Horizontal fragmentation essentially relates to various acts which deal with specific issues, regardless of whether these acts operate in the national, provincial or local spheres. The current framework of environmental legislation prescribes a multitude of procedures, processes and environmental management tools that cause an overlap of jurisdictions and give rise to confusing authorisation processes and procedures that must be followed by a prospective authorisation applicant. ${ }^{9}$ There are also various relevant competent authorities involved, conflicting mandates and jurisdictions, and other legislation that may, in addition, be applicable directly or indirectly. Some examples are discussed below.

In terms of the agricultural sector, the Conservation of Agricultural Resources Act 43 of 1983 provides for control measures which must be complied with by land users; $^{10}$ the Fertilizers, Farm Feeds, Agricultural Remedies and Stock Remedies Act 36 of 1947 provides for registration of fertilizers, farm feeds, agricultural remedies, stock remedies, sterilisation plants and pest control operators; $^{11}$ and the Subdivision of Agricultural Land Act 70 of 1970 requires a

9 This exposition is based on a study recently concluded in terms of which various environmental acts were analysed in order to determine the fragmented nature of authorisation provisions, various competent authorities, and various processes contained in environmental acts. See for the full report, CEM Report 82-200. This report specifically discusses authorisation processes and relevant competent authorities in terms of the National Nuclear Regulator Act 47 of 1999, the Hazardous Substances Act 15 of 1973, the Subdivision of Agricultural Land Act 70 of 1970, the Conservation of Agricultural Resources Act 43 of 1983, the National Water Act 36 of 1998, land use and planning legislation, and environmental impact assessment in terms of the Environment Conservation Act 73 of 1989, the Atmospheric Pollution Prevention Act 45 of 1965, and the National Heritage Resources Act 45 of 1999.

10 S 6(1).

11 S 3(1)(a). 
written authorisation by the Department of Agriculture before agricultural land may be subdivided. ${ }^{12}$

Inland water resources are principally regulated by the National Water Act 36 of 1998 (hereafter the NWA), which provides for, amongst others, water use licences, ${ }^{13}$ provisions on existing lawful water uses, ${ }^{14}$ authorisation of controlled activities, ${ }^{15}$ and registration of dams that pose a safety risk. ${ }^{16}$ Other acts are however also applicable to the conservation of water resources. Section 20 of the Environment Conservation Act 73 of 1989 (hereafter ECA), requires, for example, that no person shall establish, provide, or operate any waste disposal site without a permit issued by the Minister of DEAT. Sections 21(f) and 21(g) of the NWA contain similar provisions that require a water-use licence by DWAF for discharging waste or water containing waste into a water resource through a pipe, canal, sewer, sea outfall or other conduit; and disposing of waste in a manner which may detrimentally impact on a water resource. It is clear in this instance that two different authorisations for the same activity, based on two different acts, administrative processes and jurisdictions, are required. ${ }^{17}$ The Water Services Act 108 of 1997 further requires approval to operate as a water services provider and an authorisation for abstracting water or discharging any effluent. ${ }^{18}$ The Mineral and Petroleum Resources Development Act 28 of 2002 requires authorisation of any mining-related activity that may affect water resources. ${ }^{19}$ This act also provides that a closure certificate may only be issued if DWAF confirmed in writing that considerations relating to water resources have been addressed. ${ }^{20}$ The Conservation of Agricultural Resources Act 43 of 1983 and the Health Act 63 of 1977 further

12 S 3. Apart from authorisation provisions in terms of these principal acts, the following acts may also be applicable to agricultural resources: the Stock Remedies Act 36 of 1947, the Agricultural Pests Act 36 of 1983; provincial legislation; and by-laws. See further Glazewski Environmental Law 184-190.

13 S 22.

14 S 34(1).

$15 \mathrm{~S} 37(2)$.

$16 \mathrm{~S}$ 120(1).

17 For fragmentation of environmental governance efforts that relate to the energy sector, see Du Plessis "Legal Mechanisms" 1-23.

$18 \mathrm{~S} 22(1)$ and 32(e).

19 S 5(3).

20 S 43(5). 
provide respectively for authorisation of agricultural activities that may influence water resources ${ }^{21}$ and regulations on new buildings and provision of sanitation. ${ }^{22}$ The Mountain Catchment Areas Act 63 of 1970 also deals with water resources, especially insofar as it relates to the conservation, use, management, and control of land situated in mountain catchment areas. ${ }^{23}$ The relevant competent authorities that deal with water resource management include, amongst others, DWAF, DEAT, DME, Department of Agriculture, and the Department of Health.

The National Environmental Management: Air Quality Act 39 of 2004 (hereafter NEMAQA) recently replaced the Atmospheric Pollution Prevention Act 45 of 1965 (hereafter APPA). ${ }^{24}$ The NEMAQA requires an atmospheric emission licence for listed activities and activities related to controlled emitters and controlled fuels. ${ }^{25}$ Some of the provisions of the APPA which are still partly in force, provide for authorisation of scheduled processes in controlled areas; authorisation for the erection, alteration or extension of plants used for the purpose of carrying on scheduled processes; and authorisation for import and manufacture of fuel burning appliances. ${ }^{26}$ The Health Act 63 of 1977 and National Road Traffic Act 93 of 1996 provide respectively for regulation of health matters connected with air pollution, ${ }^{27}$ and transportation of goods that may affect air quality. ${ }^{28}$ Relevant competent authorities include, amongst others, DEAT, the Department of Health, the Department of Transport, and metropolitan and district municipalities.

$21 \mathrm{~S} 6(1)$.

22 S 34(1).

23 Mountain Catchment Areas Act 63 of 1970.

24 Air quality management was for many years regulated by APPA. Although APPA has been replaced by the NEMAQA (see GN R898 of 9 September 2005), only some of the provisions of the latter act are in force. Provisions of the APPA which are consequently still applicable include s 21, 22, 36, 49, 51(1)(e), 51(1)(f), 51(3), 60 and 61 . Notably the provisions relating to APPA Schedule 2 permits are still in force and will only in future be replaced by the provisions of NEMAQA in this regard. It should also be noted that the Occupational Health and Safety Act 85 of 1993 that provides for the health and safety of mine employees may also be relevant insofar as it relates to the health and safety of mine workers in relation to air pollution.

25 S 22, 25(1), 28(1), 37(1) and 42(1).

26 S 9(1).

27 S 27(1).

28 S 54. 
Biodiversity resources are regulated by various acts. ${ }^{29}$ The National Environmental Management: Biodiversity Act 10 of 2004 is the principal act and requires authorisation of activities relating to, amongst other, specimens of listed, threatened, or protected species; alien species; listed invasive species; genetically modified organisms (hereafter GMOs); and bioprospecting. ${ }^{30}$ The National Forests Act 84 of 1998 provides for authorisation of, inter alia, activities relating to the use of natural forests, establishment of plantations, authorisation procedures for various forestry activities, and activities relating to the selling of forest produce. ${ }^{31}$ The Genetically Modified Organisms Act 15 of 1997 is the principal act in terms of which GMOs are regulated. The Act specifically requires authorisation of activities relating to the development, production, use and application of GMOs. ${ }^{32}$ The National Environmental Management: Protected Areas Act 57 of 2003 is also applicable to biodiversity resources insofar as it relates to authorisation of activities, including commercial prospecting and mining activities, in nature reserves and world heritage sites. ${ }^{33}$ Relevant competent authorities include, inter alia, DEAT, DWAF, and the Department of Agriculture.

Regulation of minerals, petroleum and energy is also based on a multitude of acts. $^{34}$ These include, inter alia, the Nuclear Energy Act 46 of 1999 which

29 Kotzé and Du Plessis "International Environmental Law" 17-19. Apart from authorisation provisions in terms of the National Environmental Management: Biodiversity Act, the following acts may also be applicable to biodiversity resources: the ECA; the Plant Breeder's Rights Act 15 of 1976; the Plant Improvement Act 53 of 1976; the Animal Improvement Act 62 of 1998; the Agricultural Pests Act 36 of 1983; the Foodstuffs, Cosmetics and Disinfectants Act 54 of 1972; the Animal Protection Act 71 of 1962; the Sea Birds and Seals Protection Act 46 of 1973; the National Veld and Forest Fire Act 101 of 1998; the National Parks Act 57 of 1976; the Management of State Forests Act 128 of 1992, provincial legislation, and numerous by-laws. See further Glazewski Environmental Law 280-291, 382-397.

30 S 57(1), 65(1), 69(1), 71(1), 78(1), 81(1), 87 and 92(1).

31 S 7(1), 10(1), 15(1), 23(1), 24(9) and 28(4).

$32 \mathrm{~S} 5$ and 14.

33 S 50(5) and 48(1).

34 These include the NEMA; the National Parks Act 57 of 1976; the NWA; the Water Services Act 108 of 1997; the APPA; the Nuclear Energy Act 131 of 1993; the Mine Health and Safety Act 29 of 1996; the Electricity Act 41 of 1987; the Petroleum Products Act 120 of 1977; the Income Tax Act 58 of 1962; and provincial legislation and by-laws. See further Glazewski Environmental Law 480-483, and Du Plessis South Africa 29-121. Du Plessis Energy Law 103, emphasises the fragmented nature of energy laws in South Africa, by 
provides for authorisation of activities relating to nuclear source materials; ${ }^{35}$ and the National Nuclear Regulator Act 47 of 1999 which provides for authorisation of activities involving nuclear installations and nuclear vessels. ${ }^{36}$ The Mineral and Petroleum Resources Development Act 28 of 2002 is applicable to mineral and petroleum resources and provides for authorisation of mining activities that may affect water resources; approval of environmental management programmes and plans relating to mining activities; reconnaissance permissions; prospecting rights; mining rights; environmental impact assessments (hereafter EIA) relating to mining activities; and authorisation of mining activities in certain areas such as national parks. ${ }^{37}$ The principal competent authorities in this regard are DME and DEAT.

Heritage resources are principally regulated by the National Heritage Resources Act 25 of 1999. The Act provides for authorisation of activities relating to, inter alia, destruction, excavation, alteration, restoration, removal, and subdivision of heritage sites and objects, and submission and approval of heritage impact assessments (hereafter HIA). ${ }^{38}$ Apart from authorisation provisions in terms of this act, the following acts may also be applicable to heritage resources: the National Monuments Act 28 of 1969; the Wreck and Salvage Act 94 of 1996; the Cultural Institutions Act 119 of 1998; the National Heritage Council Act 11 of 1999; the NEMA; provincial legislation, and bylaws. ${ }^{39}$ The relevant competent authorities include SAHRA, DEAT and the Department of Arts and Culture.

Marine resources and marine pollution are regulated by various issue-specific acts. $^{40}$ The Marine Living Resources Act 18 of 1998 (hereafter MLRA) provides

stating that laws relating to energy usually "address the cycle of sourcing, exploitation, generation or production, transportation, distribution or consumption. The topics are either not dealt with or to be found in different pieces of legislation."

35 S 34(1), 35(1) and 46(1).

36 S 20(1).

37 S 5(3), 5(4), 13(1), 16(1), 20(1), 22(1), 22(4), 27(1), 39(1), 48(1), 74(1), 76(1), 79(1) and 83(1).

38 S 27(18), 29(10), 31(7), 32(17), 34(1), 35(4), 36(3), and 38.

39 See further Glazewski Environmental Law 517-528.

40 Apart from the acts discussed here, the following acts may also be applicable: the Maritime Zones Act 15 of 1994; the Sea Birds and Seals Protection Act 46 of 1973; the 
for authorisation of activities relating to the fishing industry, including, authorisation of commercial fishing, subsistence fishing, mariculture, fish processing plants, and fishing vessels. ${ }^{41}$ The Marine Pollution (Control and Civil Liability) Act 6 of 1981 regulates marine pollution by prescribing authorisation requirements for, amongst others, offshore installations and vessels carrying possible polluting substances. ${ }^{42}$ The Dumping at Sea Control Act 73 of 1980 and the Sea Shore Act 21 of 1935 are also relevant for marine pollution insofar as they respectively provide for authorisation of dumping of polluting substances at sea, ${ }^{43}$ and authorisation of activities involving removal of resources found in the ocean and on sea shores. ${ }^{44}$ Competent authorities responsible for regulation include, amongst others, DEAT, the South African Maritime Safety Authority, and the Department of Transport.

\subsubsection{Framework/sectoral fragmentation}

One of the most typical examples of framework/sectoral fragmentation is perhaps the legislative framework dealing with EIA. Chapter 5 of the NEMA, as amended by the second National Environmental Management Amendment Act 2004 primarily regulates EIA as environmental framework legislation. ${ }^{45}$ Apart from the NEMA provisions on EIA, some sectoral acts also provide for EIA procedures. These acts include, inter alia, the National Heritage Resources Act 25 of 1999, and the Mineral and Petroleum Resources Development Act 28 of 2002. These acts respectively require a $\mathrm{HIA}^{46}$ and an EIA which must be

Health Act 63 of 1977; provincial legislation, and by-laws. See further Glazewski Environmental Law 421-422.

41 S 18(1), 23(1), 39(1) and 40.

$42 \mathrm{~S} 21(1)$ and 24(1).

43 S 3(1).

$44 \quad S 3(2)$ and 5(1).

45 EIA was previously regulated in terms of the ECA. S 24 of the NEMA, as amended by the National Environmental Management Amendment Act 8 of 2004, currently regulates EIA in South Africa. It is envisaged that the amended s 24 will come into force early in 2006. It should also be noted that some aspects relating to EIA are either directly or indirectly dealt with by, amongst others, the Development Facilitation Act 67 of 1995, the NWA, and the MLRA which gives rise to further horizontal fragmentation of legislation.

46 S 35(4) of the National Heritage Resources Act 25 of 1999. 
conducted before commencement of certain mining activities. ${ }^{47}$ Authorities responsible for the regulation of EIAs include, amongst others, DEAT, SAHRA and DME.

\subsubsection{Inter-sectoral fragmentation}

The legislative framework is also fragmented within various specific sectors. Pollution control and waste management serves as an example in this regard. ${ }^{48}$ Glazewski ${ }^{49}$ observes that:

Pollution control laws have traditionally been applied by different national, provincial and local levels of government, corroborating the general criticism that the administration of environmental laws is diffuse and uncoordinated. This situation has been exacerbated rather than simplified by the new Constitution, as seen in chapter 4, which creates concurrent national, provincial and, in some instances, local government legislative competence in the sphere of pollution control. Moreover, administrative acts, such as the issuing of permits and the granting of exemptions, are carried out by officials at all levels of government. ${ }^{50}$

Regulation of pollution and waste management in South Africa is thus environmental media-specific and based on various acts and different competent authorities. There is, for example, no single, integrated act that regulates land, air, water and noise pollution in an integrated fashion. Instead, the regulatory framework for pollution consists of a multitude of acts, including amongst others: the NEMA ${ }^{51}$; the ECA; ${ }^{52}$ the NWA; the Health Act 63 of 1977;

47 S 22(4) of the Mineral and Petroleum Resources Development Act 28 of 2002.

48 See further Kotzé and Feris South Africa 39-44.

49 Glazewski Environmental Law 533-536.

50 See also Bosman, Kotzé and Du Plessis 2004 19(2) SA Public Law 411-421 for a discussion on fragmentation of governance efforts caused by the 1996 Constitution.

51 It should however be pointed out that certain provisions of the NEMA attempt to integrate pollution control since these provisions apply universally to all types of pollution and not specific sectors such as water, soil or air pollution. See in this regard s 28 and 30 which respectively deal with pollution prevention and remediation and emergency incidents.

52 The same can also be said for s 31A of the ECA which applies universally to all pollution and environmental degradation. This provision affords the Minister, competent authority, local authority or government institution wide-ranging powers to direct persons who seriously damage, endanger or detrimentally affect the environment, to cease an activity, or to take such steps as may be prescribed by the relevant authority. 
the Foodstuffs, Cosmetics and Disinfectants Act 54 of 1972; the International Health Regulations Act 28 of 1974; the Nuclear Energy Act 46 of 1999; the Nuclear Regulator Act 47 of 1999; the Conservation of Agricultural Resources Act 43 of 1983; the Fertilisers, Farm Feeds, Agricultural Remedies and Stock Remedies Act 36 of 1947; the Agricultural Pests Act 36 of 1983; the Occupational Health and Safety Act 85 of 1993; the Advertising on Roads and Ribbon Development Act 21 of 1940; the National Building Regulations and Building Standards Act 103 of 1977; the Aviation Act 74 of 1962; the Criminal Procedure Act 51 of 1977; provincial legislation; and various by-laws. ${ }^{53}$ Moreover, issue-specific acts require several authorisations for possible polluting activities. These include, for example, the Hazardous Substances Act 15 of 1973 insofar authorisation requirements relate to activities involving specifically listed hazardous substances; ${ }^{54}$ the provisions of the NEMAQA and APPA insofar as it relates to air pollution; and the provisions of legislation relating to marine pollution. Competent authorities include, amongst others, DEAT, DWAF, DME, the Department of Transport, the Department of Agriculture, and the Department of Health. Fragmentation caused by this diffuse legislative and institutional regime is further exacerbated by the fact that South Africa does not have effective legislation that deals with integrated pollution prevention and control. ${ }^{55}$

A further example of inter-sectoral fragmentation is the current land use management and planning framework in South Africa. ${ }^{56}$ Scheepers ${ }^{57}$ observes in this regard that land degradation is a matter of real concern in South Africa. In terms of a more sustainable land-use strategy, it is emphasised that more

53 See further Glazewski Environmental Law 533-630. Apart from the plethora of sectoral legislation that regulates pollution control and waste management, principles of common law, including the law of delict, criminal law, neighbour law and the law of nuisance are also applicable. See further Glazewski Environmental Law 533.

54 S 3(1), 3A(1) and 4(1).

55 Despite this, it is noted that some endeavours are afoot to address the fragmented pollution and waste regulation regime. These include, amongst others, the White Paper on Integrated Pollution and Waste Management discussed in par 4.3 below, as well as the National Waste Management Strategy and the Integrated Waste Management Bill, the latter, which is in the process of being developed.

56 See for a detailed discussion Kotzé Strategies 2, 5-6; and CEM Report 136-154.

57 Scheepers Practical Guide 240. 
effective resource-use planning, land and resource management strategies, and adequate monitoring and maintenance of land use development are needed. ${ }^{58}$ A more sustainable land use strategy may however not be achieved because

...the responsibility for natural resource management is spread over different national and provincial ministries, each carrying out their jurisdictions as specified by the different Acts they have to implement. $^{59}$

The result is that the current legal, institutional, governance and management framework, do not facilitate integrated approaches to land use and planning. An integrated approach to environmental governance efforts, land use and planning issues, may accordingly be significant to achieve a sustainable land use strategy in South Africa.

It is noted in this regard that the land use management and planning regime in South Africa forms an integral part of the entire environmental governance effort. Land use lies at the core of some of the most contentious issues surrounding development initiatives. This is especially true in the case of developing countries such as South Africa. During consideration of the viability of a proposed development, some pertinent issues need to be addressed, including amongst others: the impact of development on the environment, jobcreation, economic growth, poverty alleviation, and provision of housing and physical infrastructure. ${ }^{60}$ A central component in these considerations is administrative decision-making by way of environmental governance efforts that are executed by various authorities in terms of a multitude of acts. Environmental governance efforts relating to land use in South Africa are fragmented along various acts and authorities that either directly, or indirectly, influence land use and planning issues. Consequently, the administration of these acts is also fragmented along the various spheres of government and

58 Scheepers Practical Guide 240.

59 Ibid.

60 Glazewski Environmental Law 195. 
different line-functionaries in each sphere. ${ }^{61}$ This point has been reiterated in the High Court of South Africa, where it was stated that:

The present application illustrates that the statutory framework regulating town planning and building regulations in its present form is fragmented and cumbersome in the extreme... It requires a vast bureaucratic machine to administer all these provisions... The system also frequently...gives rise to conflicting and inconsistent decisions taken by different functionaries, officials and organs at different levels of local and provincial government. It would be of great assistance to everyone involved in the process... if the administrative machinery required to regulate these matters could be consolidated, simplified and streamlined. ${ }^{62}$

The legislative framework pertaining to land use and planning further consists of various acts. ${ }^{63}$ Some of the principal acts are the Development Facilitation Act 67 of 1995 that provides for authorisation of land development activities; ${ }^{64}$ the Physical Planning Act 125 of 1991 which provides for authorisation of town planning schemes; ${ }^{65}$ and the Subdivision of Agricultural Land Act 70 of 1970 insofar as it provides for authorisations before agricultural land may be subdivided. ${ }^{66}$

61 Glazewski Environmental Law 200-202.

62 Camps Bay Ratepayers and Residents Association v The Minister of Planning, Culture and Administration (Western Cape) 20014 SA 301 (CPD).

63 The following acts may also be applicable to land use and planning: the Upgrading of Land Tenure Rights Act 122 of 1991; the Restitution of Land Rights Act 22 of 1994; the Communal Property Associations Act 28 of 1996; the Land Reform (Labour Tenants) Act 3 of 1996; the Interim Protection of Informal Land Rights Act 31 of 1996; the Extension of Security of Tenure Act 62 of 1997; the Prevention of Illegal Eviction and Unlawful Occupation of Land Act 19 of 1998; the Designated Areas Development Act 87 of 1979; the Less Formal Township Establishment Act 113 of 1991; the Local Government Transition Act 209 of 1993; the Local Government: Municipal Structures Act 117 of 1998; the Local Government: Municipal Systems Act 32 of 2000; the National Building Regulations and Building Standards Act 103 of 1977; and provincial legislation and bylaws. See further Glazewski Environmental Law 187-190, 207-215, Scheepers Practical Guide 1-356, and CEM Report 136-154.

64 S 31(1), 42(1) and 61(1).

65 S 27(1) and 29.

$66 \mathrm{~S} 3$. It must be pointed out that there are some initiatives afoot to address fragmentation of the land use management regime. This may arguable be done by way of the Land Use Management Bill which is in the process of being developed. 
The exposition above demonstrates that governance efforts in terms of the legislative framework are fragmented in a horizontal, vertical, framework/sectoral and inter-sectoral sense. The current environmental governance effort is silo-based and environmental media-specific with various acts, provisions, authorisation procedures and competent authorities involved. Fragmentation of the legislative framework may arguably lead to unsustainable governance efforts which are based on a time-consuming, onerous, costly, nonstandardised and confusing legislative basis.

\subsection{Reasons for fragmentation}

The reason for the existence of fragmentation may be attributed to, inter alia, historical developments of the South African governmental sphere, especially insofar as it relates to South Africa's colonial and apartheid past. ${ }^{67}$ Former colonies tend to replicate the judicial, executive, legislative and administrative structures of the former coloniser. ${ }^{68}$ An imbalance is accordingly created because when these structures are imposed, they "...create a wide gulf between formal procedures and actual practices", resulting in fragmented structures, processes and governance efforts. ${ }^{69}$ Developing countries such as South Africa, furthermore inherited fragmented and uncoordinated legislation that paid little thought to sustainability and an integrated, ecosystem-orientated legal regime that permits a holistic view of the ecosystem and of the interrelationships and interactions within it. ${ }^{70}$ Rather than advocating sustainability and an integrated approach to environmental management and governance, past practices, legislation, and policies were essentially concerned with the facilitation of resource allocation and resource exploitation. ${ }^{71}$

67 Du Plessis 1995 SAJELP 23-36.

68 Sharkansky Public Administration 32.

69 Ibid.

70 Du Plessis and Nel 2001 8(1) SAJELP 2.

71 Ibid. 
In the environmental context, South Africa furthermore does not have a centralised lead agent to directly control environmental matters in an integrated fashion. ${ }^{72}$ This is because the DEAT does not assume the role of a strong, centralised lead agent that has total control over all environmental matters. ${ }^{73}$ The DEAT rather acts as a coordinator by providing framework guidance. ${ }^{74}$ It is emphasised that fragmentation is a direct result of South Africa's decentralised environmental governance structure. ${ }^{75}$ This is contrary to centralisation endeavours elsewhere in the world. Bray ${ }^{76}$ points out in this regard that international trends, such as the American and Australian approaches, favour the centralisation of powers with regard to environmental administration and that appeals have been made for the integration and administration of environmental affairs by the national sphere of government.

A further concern which may cause fragmentation is possible confusion and tension created by environmental legislation with regard to competencies. Disputes may arise because of the competencies listed in schedules 4 and 5 to the 1996 Constitution, read with the definition of 'environment' in the NEMA. ${ }^{77}$ For example, national government departments have custodianship over natural resources. Therefore, aspects such as minerals, the marine environment, and inland water resources are not listed in schedules 4 and 5, although they are integral components of the environment as defined in the

72 CEM Report 64, and Du Plessis and Nel 2001 8(1) SAJELP 26-27.

73 Lawrence 1999 9(1) SAJELP 62, furthermore highlights the difficulties faced by the DEAT by stating that the department "...has had to jostle for attention and resources. It has not been a prestigious portfolio in Cabinet, nor has it been a department that commanded a large slice of the national budget".

74 Kotzé "Co-operative Environmental Governance" 168, and Du Plessis and Nel 2001 8(1) SAJELP 26-27.

75 Glazewski Environmental Law 105-107. It should furthermore be noted in this context that the aim of reforms addressing fragmentation, is not to surrender the duty by DEAT as the lead agent to make a decision. It is rather to reduce duplication and inconsistency between various competences.

76 Bray 1995 (10) SA Public Law 181.

77 Bosman, Kotzé and Du Plessis 2004 19(2) SA Public Law 411-421, Glazewski Environmental Law 109-117, and Bray 2005 (3) JCRDR 361-363. It is also stated that the current constitutional dispensation entrenches semi-federalism which does not further integration of current fragmented legislation, and fragmented regulatory control. See in this regard Bond and Stein Competing Discourses 332. 
NEMA, and identified as a concurrent national and provincial competency. ${ }^{78}$ Confusion may thus arise as to which government sphere, or line functionary, is responsible for which functional area. ${ }^{79}$

Glazewski $^{80}$ further notes that a reason for fragmentation may be attributed to the very nature of environmental management. Environmental management seeks to encompass a vast variety of considerations such as natural resources, cultural resources, pollution control, land use planning and waste management. It is accordingly a broadly defined concept that has to fit within the narrowly defined functional areas of government. ${ }^{81}$ This may create further confusion and essentially gives rise to a real need for coordination, co-operation and integration.

The problem of fragmentation is exacerbated by the 1996 Constitution that established nine provinces. ${ }^{82}$ This may essentially lead to the encroachment of various environmental departments, or line functionaries, into the jurisdictional areas of line functionaries and departments that are not principally responsible for environmental governance. Glazewski ${ }^{83}$ observes in this regard that the various provincial departments of environmental affairs that function under the coordination of DEAT "...have no consistent or logical home in the new provinces and in each case environmental affairs finds itself with some odd bed-fellows". 84

78 Bosman, Kotzé and Du Plessis 2004 19(2) SA Public Law 411-421, and Glazewski Environmental Law 109-117.

79 It has even been stated in this regard that ch 5 of the NEMA that provides for integrated environmental management (hereafter IEM), "...amplifies asymmetry in an already terribly uneven regulatory and administrative environment", Bond and Stein Competing Discourses 332. This view accords with the contention of Glazewski Environmental Law 108, that environmental management as it currently exists in South Africa may give rise to further fragmentation because of the all-encompassing nature thereof.

80 Glazewski Environmental Law 108.

81 Glazewski Environmental Law 108.

82 S 103 of the 1996 Constitution. See also Du Plessis 1995 SAJELP 23-36 for an in-depth discussion.

83 Glazewski Environmental Law 107.

84 Further confusion is attributed to the fact that nature conservation is in some instances located in a different department than the environmental departments that are traditionally deemed to be responsible for executing environmental management functions. Glazewski Environmental Law 107, and Du Plessis 1995 SAJELP 23-36. 
It has been noted that the land use and planning regime in South Africa is also fragmented. There may be a number of reasons for this fragmentation. Prior to the new constitutional dispensation in South Africa, governance in relation to land use was essentially concerned with development of the former "white areas", whilst a "crude and rudimentary planning system" applied in the historically "African" areas. $^{85}$ The emphasis was arguably on social engineering, rather than on sustainable environmental governance. Past practices pertaining to land use and planning were accordingly significantly influenced by the apartheid ideology with largely unsustainable consequences. It has been observed in this regard that past land use practices were essentially control-orientated, rather than development-orientated; reactive rather than proactive; and blueprint-orientated rather than process-orientated. ${ }^{86}$ The result is that the current land use and planning framework is to a large extent fragmented, unequal and incoherent. ${ }^{87}$

\subsection{Results of fragmentation}

Fragmentation poses various disadvantages, ${ }^{88}$ which may include, amongst others: duplication and overlap of the governance effort, with all organs of state focusing on environmental authorisation processes without having resources available to do post-authorisation follow-up; costly delays in decision-making; inefficient arrangements between organs of state that control similar activities or proposals; significant gaps in control arrangements, whilst some pertinent

85 Glazewski Environmental Law 197. It has been observed in this regard that "[t]he apartheid city, although fragmented along racial lines, integrated an urban economic logic that systematically favoured white urban areas at the cost of black urban and peri-urban areas". See in this regard Fedsure Life Assurance v Greater Johannesburg Transitional Metropolitan Council 199812 BCLR 1458 (CC).

86 Claassen and Milton Land-use Planning 716.

87 Glazewski Environmental Law 197.

88 Although fragmentation poses several disadvantages, it may be argued that in some instances, a fragmented approach to environmental governance may hold several benefits. These include, amongst others, the development of specialised skills and capacities which avoids the situation of "jack of all trades and master of none". The principle of multiple redundancies may also be relevant. In terms of this principle there should always be a back-up system in the instance where a certain system may be able to address a problem or concern where the other system fails. Fragmentation may also provide for a review process of some sorts where one environmental department can comment and make recommendations on decisions taken by another. 
issues are not controlled at all; inconsistent behaviour by government officials; conflicting conditions in authorisations; ineffective governance; and externalisation of governmental inefficiencies to development costs which may result in negative impacts on development. ${ }^{89}$ Moreover, it is evident from this exposition that the various disadvantages posed by fragmentation may ultimately inhibit the achievement of sustainable service-delivery results.

Further disadvantages of fragmented environmental governance efforts include that: it is costly and time-consuming; it negates the possible resolution of common problems and concerns; it does not lead to sustainable governmental service delivery efforts; it is not an all-inclusive process that involves interested and affected parties that may be affected by government action; it does not provide for streamlined and aligned governance efforts; it does not enable the utilisation of various tools for governance; it is aimed at achieving single policybased objectives rather than objectives that may be common to various policies; and it may lead to results contrary to democratic governance that should ideally be based on the realisation of fundamental human rights, including the section 24 environmental right. $^{90}$ Moreover, fragmented governance may lead to dumping of problems and costs by one organ on another, conflicting programmes and policy goals, duplication, inadequate sequencing and inadequate response to needs in terms of service-delivery. ${ }^{91}$ In terms of environmental governance, fragmented governance is furthermore contrary to the very nature of the environment as an integrated, inter-related and holistic phenomenon. ${ }^{92}$ In short, fragmented governance is the direct opposite of holistic governance, and may, based on the disadvantages discussed above, lead to unsustainable results.

89 Nel, Kotzé and Snyman "Strategies" 3.

90 Nel, Kotzé and Snyman "Strategies" 13-14.

91 See for a more comprehensive discussion Perri 6 et al Towards Holistic Governance 3739.

92 The integrated and holistic nature of the environment is evident from the s 1 NEMA definition of "environment", which explains that environment means: the surroundings within which humans exist and that are made up of the land, water and atmosphere of the earth; micro-organisms, plant and animal life; any part or combination of the foregoing and the interrelationships among and between them; and the physical, chemical, aesthetic and cultural properties and conditions of the foregoing that influence human health and wellbeing. 


\section{$3 \quad$ Holistic governance}

Fragmented governance should be understood in the context of Figure 1 below. Figure 1 represents the different steps that need to be achieved in a gradual fashion for the eventual achievement of holistic governance.

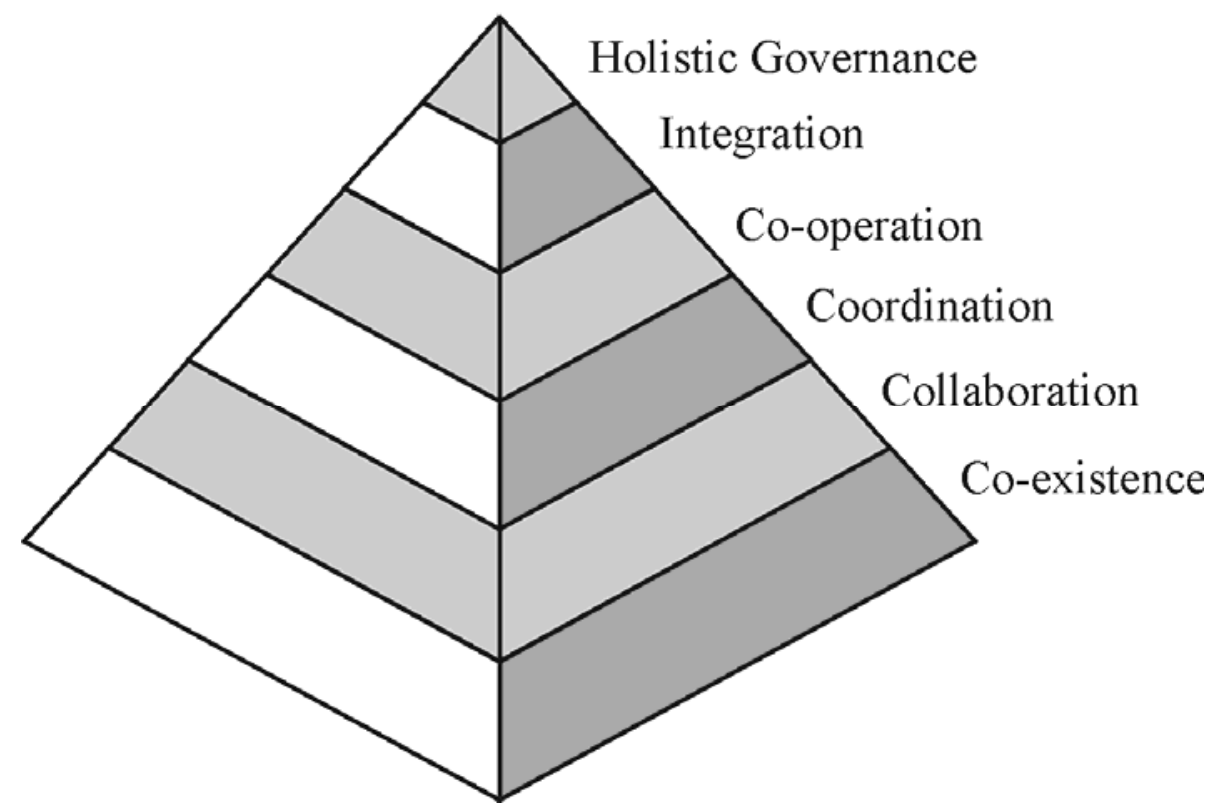

Figure 1: A Phased Approach for Achieving Holistic Governance

Holistic governance arguably represents the ideal form of governance. Evidence for this may be found in past and present efforts to establish holistic governance. ${ }^{93}$ Holistic governance entails a re-invention of current governance structures, policies and procedures and should be primarily focused on

...delivering integrated policies and practices delivering genuinely desirable outcomes to meet real needs. ${ }^{94}$

The aim of these endeavours should be to improve the effectiveness and efficiency of service-delivery to the public through governance, in order, inter

93 See Perri 6 et al Towards Holistic Governance 9-27 for a discussion on the comprehensive undertakings to establish holistic governance in the United Kingdom.

94 Perri 6 et al Towards Holistic Governance 1. 
alia, to achieve sustainable governance results. Holistic governance is not the mere piecing together of partial perspectives. Rather it recognises the notion that crosscutting issues, such as the achievement of sustainability, cannot be solved in isolation. It thereby emphasises the need for a coordinated response from various organisations. ${ }^{95}$ Given the ultimate goal of holistic governance, it may be defined for the purpose of this article as:

The ideal form of government which is established by way of collaboration, coordination, co-operation and integration of policies, regulation, service provision and scrutiny or assessment functions of co-existing governmental organs into a single system of government in order to achieve sustainable results. ${ }^{96}$

Integration, co-operation, coordination and collaboration in this context, are all methods to achieve holistic governance. Collaboration and coordination describe the situation where policies, regulation and scrutiny functions are joined-up, but not necessarily mutually reinforcing. These strategies answer the question: what can be done together ${ }^{97}$ Collaboration and coordination are furthermore respectively defined as 'to work together', and to make things, people, structures and parts function together efficiently and in an organised way. ${ }^{98}$ Although these definitions describe the coherence function of collaboration and coordination, it is clear that the achievement of a common goal or objective is not included. In other words, whilst the need for coherence is highlighted by these concepts, the actual result is not provided for. For the purpose of this article, the result to be achieved is that of sustainability, especially insofar as it relates to fragmented environmental governance efforts and optimisation of service-delivery efforts.

Co-operation and integration on the other hand, ask the questions: what can be done together?; who needs to be involved?; what are the mutually reinforcing objectives?; and how should one go about to achieve these objectives? The

95 Meijers and Stead "Policy Integration" 3.

96 As adapted from Perri 6 et al Towards Holistic Governance 28-29.

97 As adapted from Perri 6 et al Towards Holistic Governance 32.

98 Crowther (ed) Oxford Advanced Learner's Dictionary 219, 257. 
nature of these concepts as evidenced from the questions, correlates with their definitions which explains co-operation and integration respectively as 'working together for a common purpose', and 'to combine two things in such a way that one becomes fully a part of the other', hence aiming to achieve the same goals or objectives. ${ }^{99}$ Moreover, whilst coordination, and collaboration, as argued above, refers to the development of ideas regarding holistic governance, integration refers to the actual implementation of these collaborative and coordinated ideas into practice. ${ }^{100}$

The foregoing exposition explains the hierarchy of the different phases necessary to achieve holistic governance. Co-existing governmental agencies need first to collaborate and coordinate their policies, regulation, service provision and scrutiny or assessment functions; before co-operation and integration can take place in an effort to achieve holistic governance. It is argued that holistic governance is an all-encompassing term that represents the ideal form of governance, by encapsulating co-existing administrative organs in a holistic fashion by way of collaboration, coordination, co-operation, and integration.

\section{$4 \quad$ Recommendations}

It has been established that the current environmental governance sphere in South Africa is fragmented. Fragmentation is not conducive to sustainable environmental governance efforts. It is proposed that fragmentation be addressed as a matter of priority. Reforms in this regard must specifically focus on integrating fragmented legislation; regulatory tools, processes and procedures in terms of legislation; and fragmented institutional and administrative structures, processes and procedures. There may be several options available to address fragmentation, and to achieve holistic governance,

99 Crowther (ed) Oxford Advanced Learner's Dictionary 257, 620.

100 Perri 6 et al Towards Holistic Governance 33. See also the discussion on the prospects for holistic governance in Perri 6 et al Towards Holistic Governance 212-242. 
wholly, or in part. These include, inter alia: the one-stop environmental governance shop, co-operative environmental governance, and integrated pollution prevention and control. ${ }^{101}$ All of these strategies exude some, or all of the elements of holistic governance discussed above. Although they may vary in terms of scope of application, and mechanisms and means to achieve holistic governance, some aspects are common to all, namely that of collaboration, co-operation, coordination and integration.

\subsection{One-stop environmental governance shop}

Firstly, integration may be achieved by establishing a single environmental governance act that provides for an integrated administration with clearly delineated roles, mandates, jurisdictions and responsibilities. ${ }^{102}$ Such an act may also provide for an integrated environmental authorisation that incorporates authorisation requirements of other environmental media-specific legislation. Sufficient provision should be made for co-operative administrative procedures that facilitate consultation and support between relevant authorities in the execution of environmental governance tasks. This form of holistic governance strongly relates to the so-called one-stop environmental governance shop. ${ }^{103}$ This may however be a cumbersome and difficult endeavour since it will require possible constitutional amendments, to schedules 4 and 5 of the 1996 Constitution which provide for the various functional areas of concurrent and exclusive legislative competence of the national, provincial and local spheres of government. It may also result in the establishment of a single "super agency" which will usurp current jurisdictions and mandates that belong to the multitude of environmental authorities in South Africa. Such an endeavour may arguably require committed political buy-in and government support, since it may necessitate surrendering of mandates and

101 See also Kotzé Legal Framework 1-400; Bray 1999 6(1) SAJELP 1-12; Bray 2005 (3) JCRDL 357-373; Du Plessis 1995 SAJELP 23-33; Kidd 1995 2(1) SAJELP 37-54; and Stein 1997 (4) SAJELP 254-268.

102 Kotzé Legal Framework 277.

103 The one-stop environmental governance shop has been established in a number of foreign countries, including, inter alia, Finland and the Netherlands. For a comprehensive discussion, see Kotzé Legal Framework 186-249. 
comprehensive administrative and governance restructuring. Although this may be the ideal in terms of the proposed model for holistic governance, it is doubtful whether the current political climate is conducive to such reforms.

\subsection{Co-operative environmental governance}

Less radical strategies to establish holistic governance may prove to be more viable. Such strategies include, for example, utilisation of co-operative governance, or co-operative environmental governance (hereafter CEG), which is firmly entrenched in South African law. ${ }^{104}$ Whereas national, provincial and local spheres in South Africa are required to co-operate with one another, this equally applies to the various departments in each sphere and government officials in all the spheres and departments. ${ }^{105}$ CEG may be defined as:

104 See eg ch 3 of the 1996 Constitution; ch 3 of the NEMA; and specific provisions of the National Water Act 36 of 1998, the Water Services Act 108 of 1997, the National Environmental Management: Biodiversity Act 10 of 2004, the Mineral and Petroleum Resources Development Act 28 of 2002, the National Nuclear Regulator Act 47 of 1999, the Local Government: Municipal Demarcation Act 27 of 1998, the Local Government: Municipal Structures Act 117 of 1998, the Local Government: Municipal Systems Act 32 of 2000, the National Environmental Management: Air Quality Act 39 of 2004, the National Environmental Management: Protected Areas Act 57 of 2003, and the National Heritage Resources Act 25 of 1999.

$105 \mathrm{~S} 41$ of the 1996 Constitution provides in this regard that:

(1) All spheres of government and all organs of state within each sphere must -

(a) preserve the peace, national unity and the indivisibility of the Republic;

(b) secure the well-being of the people of the Republic;

(c) provide effective, transparent, accountable and coherent government for the Republic as a whole;

(d) be loyal to the Constitution, the Republic and its people;

(e) respect the constitutional status, institutions, powers and functions of government in the other spheres;

(f) not assume any power or function except those conferred on them in terms of the Constitution;

(g) exercise their powers and perform their functions in a manner that does not encroach on the geographical, functional or institutional integrity of government in another sphere; and

(h) co-operate with one another in mutual trust and good faith by -

(i) fostering friendly relations;

(ii) assisting and supporting one another;

(iii) informing one another of, and consulting one another on, matters of common interest;

(iv) co-ordinating their actions and legislation with one another;

(v) adhering to agreed procedures; and

(vi) avoiding legal proceedings against one another. 
The integration of the different spheres of government and line functionaries at international, intra-regional and intra-governmental level; co-operation between individual government officials in each sphere/line functionary; co-operation between government officials in different spheres/line functionaries; integration of policy, regulation methods and tools, service provision and scrutiny; and co-operation with industry and the public in order to achieve the principles of sustainability. ${ }^{106}$

The structure of a state is one of the factors that determine which sphere of government is responsible for which specific governance activities. ${ }^{107}$ South Africa is a unitary state with federal characteristics, which means that specific spheres and line functionaries of government are responsible for the execution of predetermined governance tasks. ${ }^{108}$ The governance structure is thus decentralised. ${ }^{109}$ This devolved structure necessitates inter-governmental relations in the context of a co-operative form of federalism, since various dynamic relationships exist between all role-players and stakeholders in government. Inter-governmental relations mean the conduct of affairs between different public sector institutions in a vertical sense (between the different spheres of government) and horizontal sense (between the different departments or line functionaries in each sphere). ${ }^{110}$ Co-operative governance in South African context is the mechanism, or strategy, that may be employed to facilitate acceptable and sustainable inter-governmental relations. The argument accordingly seems to be that co-operative governance is based on the decentralised and devolved governance structure,

....and that the three spheres working harmoniously together are more likely to address challenges than if they were acting on their own or alternatively in competition with one another. ${ }^{111}$

CEG is comprehensively provided for in South African law. The primary act in this regard is the NEMA which aims to, amongst others, provide for

106 Kotzé Legal Framework 56.

107 Theunissen Administering National Government 12.

108 Theunissen Administering National Government 126.

109 Reddy 2001 20(1) Politeia 21-39.

110 Besdziek Provincial Government 191, and Du Plessis and Nel 2001 8(1) SAJELP 1-37.

111 Reddy 2001 20(1) Politeia 26. 
...cooperative environmental governance by establishing principles for decision-making on matters affecting the environment, institutions that will promote co-operative governance, and procedures for coordinating environmental functions exercised by organs of state. ${ }^{112}$

This is done by, inter alia: environmental management co-operation agreements, environmental management and implementation plans, the Committee for Environmental Coordination, procedures for inter-governmental conflict management, ${ }^{113}$ cross-consultation as well as the various mechanisms provided for in environmental sectoral legislation. ${ }^{114}$

The recently-promulgated Inter-governmental Relations Framework Act 13 of 2005 (hereafter IRFA) ${ }^{115}$ may also be a possible solution to foster CEG in South Africa. The overall aim of the Act is to establish a framework for the national, provincial and local spheres of government to promote and facilitate inter-governmental relations; to provide for mechanisms and procedures to facilitate settlement of inter-governmental disputes; and to provide for matters incidental thereto.

Specific objectives of the IRFA include: to provide, within the ambit of cooperative governance as established by the 1996 Constitution, a framework for the various spheres of government and all organs of state to facilitate coordination in the implementation of policy and legislation, including coherent government, effective provision of service, monitoring and implementation of policy and legislation; and realisation of national priorities. ${ }^{116}$ The Act recognises that the South African governance framework is fragmented along three autonomous, yet, inter-dependent and inter-related spheres; and that all

112 National Environmental Management Act 107 of 1998.

113 See ch 3, 4 and 8 of the NEMA.

114 See eg National Water Act 36 of 1998, the Water Services Act 108 of 1997, the National Environmental Management: Biodiversity Act 10 of 2004, the Mineral and Petroleum Resources Development Act 28 of 2002, the National Nuclear Regulator Act 47 of 1999, the Local Government: Municipal Demarcation Act 27 of 1998, the Local Government: Municipal Structures Act 117 of 1998, the Local Government: Municipal Systems Act 32 of 2000, the National Environmental Management: Air Quality Act 39 of 2004, the National Environmental Management: Protected Areas Act 57 of 2003, and the National Heritage Resources Act 25 of 1999. See also Kotzé Legal Framework 109-119.

115 Published in GG No 27031 of 26 November 2004.

116 S 3. 
spheres must provide effective, efficient, transparent, accountable and coherent governance in order to secure the well-being of people and the progressive realisation of their constitutional rights. ${ }^{117}$ Further, that one of the most pervasive challenges facing government is redressing the legacies of apartheid and discrimination, which arguably includes the fragmented environmental governance effort in South Africa; and that this challenge is best addressed through a concerted effort by all spheres of government to work together in the provision of services. ${ }^{118}$ The Act also recognises that co-operation in government depends on a stable and effective system of governance for regulating the conduct of relations and the settlement of inter-governmental disputes. $^{119}$

The Act applies to all spheres of government and to all organs, departments, or line functionaries that exist in these spheres. ${ }^{120}$ The objectives of the Act should be promoted by taking into account the circumstances, material interests and budgets of other spheres of government and organs of state when exercising statutory powers or performing statutory functions. ${ }^{121}$ Spheres of government and organs of state should also consult other affected organs in accordance with formal procedures provided by specific legislation or accepted convention. ${ }^{122}$ Where no such procedures or convention exist, consultation should be in the manner best suited to the circumstances by way of direct contact or any relevant inter-governmental structures. ${ }^{123}$ Other factors that must be taken into account when promoting the objectives of the Act include: coordinating actions when implementing policy or legislation affecting the material interests of other spheres of government and government organs; avoiding unnecessary and wasteful duplication or jurisdictional contests; taking all reasonable steps to ensure sufficient institutional capacity and effective 
procedures; ${ }^{124}$ and participating in inter-governmental structures, including, for this purpose, the settlement of inter-governmental disputes. ${ }^{125}$ Chapter 2 provides for a number of inter-governmental structures that may be employed to establish co-operative governance. These include the President's Coordinating Council (hereafter the PCC); and inter-governmental forums in the national, provincial and local spheres of government. These forums act as a platform for inter-governmental consultation and discussion, and although they are not deemed to be executive decision-making bodies, they may adopt resolutions or make recommendations in terms of agreed procedures. ${ }^{126}$ It is envisaged that this legislative development may contribute to enhance uncooperative governance practices, especially in environmental context where reforms are particularly required.

Although co-operative governance is comprehensively provided for in South African environmental law, it is noted that fragmentation still persists in the environmental governance sphere. Evidence moreover suggests that CEG seems to have little effect on current uncooperative administrative practices in the environmental governance sphere. ${ }^{127}$ One may come to the conclusion that government does not fully appreciate the benefits that the concept poses as a strategy to further integration by way of aligned, co-operative and mutually reinforcing governance practices.

\subsection{Integrated pollution prevention and control (IPPC)}

South Africa furthermore has a policy on integrated pollution and waste management (hereafter IPWM) in the form of the White Paper on Integrated Pollution and Waste Management for South Africa: A Policy on Pollution Prevention, Waste Minimisation, Impact Control and Remediation (hereafter the

124 These measures may include to consult, co-operate and to share information with other organs of state; and to respond promptly to requests by other organs of state for the sake of consultation, co-operation and information sharing. See s 4(e)(i)-4(e)(ii).

125 S 4(c)-4(f).

126 S 29.

127 CEM Report 1-374. 
White Paper). ${ }^{128}$ The White Paper is the domestic version of Integrated Pollution Prevention and Control (hereafter IPPC) and has been entrenched at policy level, albeit in the form of IPWM. The concept of IPPC is widely employed in various countries, including Finland and the Netherlands, as a mechanism to address fragmented environmental governance efforts. ${ }^{129}$ IPPC may be defined as:

A holistic regulatory regime that employs technology-based pollution standards, with the main objective to control industrial pollution through an integrated authorisation procedure and a centralised, or fully co-ordinated administration, by having regard to all emissions from an industrial installation to all environmental media in a coherent, holistic, inter-related and inter-dependent fashion. ${ }^{130}$

South Africa has thus made some progress to date in the development of the concept for domestic purposes in the form of the White Paper. This policy document recognises the unsustainable results of the current fragmented environmental governance regime. ${ }^{131}$ It is specifically stated that:

Although South Africa has extensive environment, pollution and waste management legislation, responsibility for its implementation is scattered over a number of different departments and institutions. The fragmented and uncoordinated way that pollution and waste is currently being dealt with, as well as the insufficient resources to implement and monitor existing legislation contribute largely to the unacceptable high levels of pollution and waste in South Africa. This White Paper will implement co-operative governance as envisaged in the Constitution. The current fragmentation, duplication and lack of co-ordination will be eliminated. The White Paper on Integrated Pollution and Waste Management will result in a review of all existing

128 Published in GG 2097817 March 2000.

129 Kotzé Legal Framework 131-140; Kotzé "Fragmented and Unsustainable Environmental Governance".

130 Kotzé Legal Framework 61.

131 It is stated in this regard that a number of limitations inhibit the achievement of sustainable IPWM. These include limits of impact management; limited civil society involvement; inadequate integration of environmental media; inadequate integration across government departments; lack of capacity to implement policies; and inadequate consideration of global environmental issues. White Paper 13. 
legislation and the preparation of a single piece of legislation dealing with all waste and pollution matters. ${ }^{132}$

The White Paper proposes a number of mechanisms to implement the objectives of the policy. The primary mechanism in this regard is a legislative programme that will culminate in new pollution and waste legislation. This proposed legislation has as its objective to, inter alia, address current legislative gaps and clarify and allocate responsibilities within government for pollution and waste management. ${ }^{133}$

"Integration" in terms of the policy should be understood as including integration of environmental media to address their interactions and overlapping management issues, and integration between DEAT and the IPWM policy and other regulatory authorities, policies, and strategies, that govern the different environmental media. ${ }^{134}$ A functional approach to integration also entails integration of source-based controls, and management of the receiving environment by way of EIA and remediation measures. ${ }^{135}$ Integration furthermore seems to be based on the different environmental media. In terms of water resources, it is specifically provided in this regard that issues requiring consideration include: the regulation of water pollution by DWAF; preventive and management measures by DME; the agricultural and domestic use of herbicides, pesticides and poisons, and their contribution to the contamination of storm water run-off; soil erosion resulting in siltation of reservoirs and high silt loads in rivers; atmospheric deposition on land and the indirect impact on surface and groundwater; and wind-blown dust and solids from tailing deposits

132 White Paper 5. It is furthermore emphasised that, due to the crosscutting nature of pollution and waste management, the involvement of the private sector, and co-operative partnerships and relationships between organs of state themselves and between government and the public sector is of vital importance for the successful achievement of the objectives of IPPC.

133 White Paper 5. It is noteworthy in this regard that the ideal of an integrated pollution control law appears to have been undermined by he promulgation of various sectoral acts which are issue or media-specific and which are administered by different environmental departments situated in various spheres of government. See also the discussion above on fragmentation.

134 White Paper 26.

135 White Paper 29. 
and their impact on water quality. ${ }^{136}$ With regard to air pollution, integration endeavours must consider regulation of air pollution by DEAT, the provinces and municipalities; pollution of water used for scrubbing air; and air pollution arising from the disposal of solid waste. ${ }^{137}$ Integration endeavours relating to land pollution should take into account regulation of land pollution by the Department of Agriculture, DWAF, DME and other pollution control authorities; the impact of land pollution on water quality; the impact of organic agricultural wastes on surface and groundwater quality; the impact of soil erosion and agricultural management practices on water quality; land pollution from liquid effluent disposal via irrigation; the impacts of industrial activities or infrastructure on surface and ground water quality in terms of related effects on land or soil; the impact of sewage treatment works; the impact of residential development; land application of sewage sludge; and the impacts of waste and hazardous waste disposal sites. ${ }^{138}$ In terms of waste regulation, integration efforts should take into account aspects relating to the regulation of waste by DEAT. ${ }^{139}$ It is noteworthy that the integrated approach advocated by this policy is explicitly based on a sectoral approach, where control measures are to be executed in relation to a specific environmental medium by specific environmental departments in various spheres of government responsible for that medium. It may be argued that this approach contradicts the principal aim of integration advocated by the generally recognised IPPC approach.

Chapter 5 of the White Paper further sets out seven strategic goals and objectives of the IPWM policy. The objectives and goals are to be achieved through the National Waste Management Strategy which also includes shortterm actions plans. ${ }^{140}$ The first goal concerns the establishment of an effective and harmonised institutional framework and integrated legislation, and is

136 White Paper 27.

137 White Paper 27-28.

138 White Paper 28.

139 White Paper 29.

140 White Paper 31. See also DEAT and DWAF National Waste Management Strategies. It should further be noted that no strategy and action plans relating to pollution control have been formulated to date. 
perhaps the most important for the purpose of this study. ${ }^{141}$ With regard to the institutional framework, it is stated that mechanisms must be established to give effect to the institutional arrangements provided for in chapter 6 of the White Paper, and that a review and audit of skills, resources, functions, and capacities in DEAT and DWAF must be conducted in order to realign them for the effective implementation of IPWM. ${ }^{142}$ It is stated in this regard that the DEAT is in the process of legislative reforms which should be completed by 2000 . At the time of writing, no significant legal reforms for the achievement of this goal have been made. Other strategic goals of the IPWM policy include pollution prevention, waste minimisation, remediation and impact management; ${ }^{143}$ holistic and integrated planning; ${ }^{144}$ participation and partnerships in IPWM; ${ }^{145}$ empowerment and education in IPWM; ${ }^{146}$ information management, $^{147}$ and international co-operation. ${ }^{148}$

Chapter 6 of the White Paper is entitled 'Governance', and deals with the role of government and stakeholders, as well as mechanisms for the enforcement of IPWM. It is provided in this regard that DEAT, as the environmental lead agent, will be the responsible and competent authority with regard to IPWM. ${ }^{149}$ The functions of DEAT include: establishing policy, strategies and legislation; coordination; enforcement; dissemination of information; appeals and participation; monitoring, auditing and review and capacity building. ${ }^{150}$ In order to execute these functions, DEAT has the power to, inter alia, enforce compliance with IPWM; bind all organs of state and spheres of government to comply with and give effect to IPWM; review the environmental impact of all

141 White Paper 32.

142 White Paper 33. Short term deliverables in this regard include, amongst others, establishment of a single, integrated and efficient administrative system to deal with environmental authorisations and EIAs; setting of national ambient quality and environmental quality standards and criteria; developing uniform procedures for setting and enforcing quality standards; and development of regulations to enforce coordinated and integrated waste management planning. See in this regard White Paper 33-34.

143 White Paper 34-39.

144 White Paper 39-40.

145 White Paper 40.

146 White Paper 40-42.

147 White Paper 42.

148 White Paper 43.

149 White Paper 45-46.

150 White Paper 46. 
government policies, strategies, plans, programmes and actions insofar as they relate to IPWM; and intervene in instances where provincial and local government are not able to fulfil their obligations. ${ }^{151}$ Other departments that may also be involved with IPWM include DWAF, DME, the Department of Health and the Department of Agriculture. ${ }^{152}$ These departments have similar functions and powers as DEAT insofar as they are responsible for a specific environmental medium. It may be derived from these provisions that, although DEAT is designated as the overall competent authority insofar as implementation of IPWM is concerned, governance tasks and mandates for the execution of sector-related or environmental media-specific IPWM matters, including water pollution, minerals, health and agriculture, are still fragmented along various autonomous departments or line functionaries of government. ${ }^{153}$ This fragmentation is also noted in terms of the provision that lead departments will retain functional integrity and accountability in executing their specific legal mandates. ${ }^{154}$ Chapter 6 also provides that provincial and local government is responsible for governance of IPWM in the provincial and local spheres. ${ }^{155}$ In terms of these policy provisions, it also seems that governance efforts in relation to IPWM remains fragmented in terms of the various spheres of government.

According to the White Paper, the environmental authorisation process in South Africa is part of the whole governance effort provided for in chapter 6 . It is specifically provided for in this regard that:

The current fragmentation, duplication and lack of coordination in the authorisation process and assessment reporting requirements will be replaced by a single streamlined and efficient administrative system.

151 White Paper 46.

152 White Paper 46-47.

153 Moreover, impact management by way of ambient standards, will be the responsibility of DWAF and DEAT. See further, White Paper 49-50. Ambient environmental quality monitoring and compliance monitoring will also be media-specific and sector-based and will be dealt with by the various spheres and line functions of government involved with IPWM. See further White Paper 50-51. This supports the argument that DEAT does not function as a strong and central regulatory lead agent, but rather as a department that coordinates functions of other departments.

154 White Paper 49.

155 White Paper 47-48. 
A simple process for environmental authorisations will be developed to ensure that activities with a possible detrimental effect on the environment are adequately regulated. ${ }^{156}$

The White Paper envisages that a single entry point for authorisation applications will be investigated for this purpose. At the time of writing, the relevant authorities have not put any formal arrangements forward in this regard. In relation to the authorisation process, subsequent policy provisions provide for the possibility to employ a wide selection of environmental management, or regulatory instruments, including, 'command and control' tools, market-based instruments, voluntary agreements, and land use planning and controls. ${ }^{157}$ It is however evident that environmental authorities still favour the use of 'command and control' tools in the form of environmental authorisations, and that no significant developments have taken place in this regard.

An analysis of the White Paper on IPWM furthermore suggests that IPWM does not comprehensively mirror the objectives, scope, and nature of IPPC as it is established internationally. ${ }^{158}$ Moreover, the most significant concern in domestic development of IPPC is the fact that these policy measures have not been comprehensively codified into environmental law. Some arrangements have been made on an ad hoc basis. Certain provisions of the NEMA attempt to integrate pollution prevention and control since these provisions apply universally to all types of pollution and not specific sectors such as water, soil or air pollution. See, for example, in this regard sections 28 and 30 which deal respectively with pollution prevention and remediation and emergency incidents. These provisions espouse a general duty of care and provide for measures to prevent, minimise and reduce pollution across all environmental media and sectors, spheres and line functionaries of government. The same can also be said for section 31A of the ECA which applies universally to all pollution and environmental degradation. This provision affords the Minister, competent authority, local authority or government institution wide-ranging 
powers to direct persons who seriously damage, endanger or detrimentally affect the environment, to cease an activity, or to take such steps as may be prescribed by the relevant authority. ${ }^{159}$ These endeavours may however not be sufficient to adequately give effect to a truly integrated approach to specifically pollution prevention and control and a more integrated approach to environmental governance efforts in general. Moreover, apart from these, no other significant developments in this regard have taken place to date to apply the concept in domestic environmental governance efforts.

It is accordingly suggested that responsible authorities should revisit the initial development of the IPWM policy. It may be necessary to, inter alia: set new objectives and priorities, reformulate some provisions of the policy where they do not adequately conform to the generally accepted concept of IPPC, provide for a uniform pollution standard which is currently lacking (for example Best Available Techniques), set new timeframes for the implementation of the policy, more comprehensively investigate best practices with regard to the formulation and implementation of IPPC at international and regional levels, and implement the policy as a matter of urgency in order to address fragmented environmental governance practices in South Africa. This may arguably contribute to streamline and integrate the current fragmented environmental governance regime, especially insofar as it relates to the fragmented pollution regulation framework.

\section{Conclusion}

South Africa is a developing country which faces many challenges. Notably, one of the most profound challenges is the manner in which the current generation addresses environmental concerns. The obligation to conserve the environment for the benefit of present and future generations is largely encapsulated within the parameters of 'governance'. Governance in this context 
requires a concerted effort of unqualified political buy-in by government and all interested and affected parties to reform the current fragmented environmental governance regime. The ultimate objective of reforms should be the achievement of sustainable benefits in an intra- and inter-generational sense.

Any envisaged reform process may arguably only have a significant influence on the governance regime in the long-term. Notwithstanding, it is proposed that government and all relevant stakeholders should take cognisance of the need for integration and holistic environmental governance. Minds should be applied and concrete action needs to be taken if fragmented environmental governance is to be steered in a holistic and sustainable direction in South Africa. Although the one-stop environmental governance shop may be the ideal option to achieve integrated, or holistic governance, other less-drastic options, such as IPPC and CEG are available to guide governance reforms on a sustainable path.

This article endeavoured to provide some insights into the current state of environmental governance in South Africa. It is hoped that the proposals forwarded herein may serve as a catalyst to spark renewed environmental governance reform initiatives, and to direct these initiatives on a more sustainable path. 


\section{Bibliography}

Perri 6 et al Towards Holistic Governance 37-39

Perri 6 et al Towards Holistic Governance: The New Reform Agenda (Palgrave Hampshire 2002) 37-39

Besdziek Provincial Government 191

Besdziek D "Provincial Government" in Venter A (ed) Government and Politics in the New South Africa $2^{\text {nd }}$ ed (Van Schaik Publishers Pretoria 2003) 191

Bond and Stein Competing Discourses 332

Bond $\mathrm{P}$ and Stein $\mathrm{R}$ "Competing Discourses of Environmental and Water Management in Post-Apartheid South Africa" in Wehrmeyer W and Mulugetta Y (eds) Growing Pains: Environmental Management in Developing Countries (Greenleaf Publishing Sheffield 1999) 332

Bosman, Kotzé and Du Plessis 2004 19(2) SA Public Law 411-421

Bosman C, Kotzé LJ and Du Plessis W "The Failure of the Constitution to Ensure Integrated Environmental Management from a Co-operative Governance Perspective" 2004 19(2) SA Public Law 411-421

Bray 2005 (3) JCRDR 361-363

Bray E "Legal Perspectives on Global Environmental Governance: South Africa's Partnership Role (Part 2)" 2005(3) Journal of Contemporary Roman-Dutch Law 361-363

Bray 1999 6(1) SAJELP 1-12

Bray E "Focus on the National Environmental Management Act: Cooperative Governance in the Context of the National Environmental Management Act 107 of 1998" 1999 6(1) South African Journal of Environmental Law and Policy 1-12 
Bray 1995 (10) SA Public Law 181

Bray E "Fragmentation of the Environment: Another Opportunity Lost for a Nationally Coordinated Approach?" 1995 (10) SA Public Law 181

CEM Report 1-374

Centre for Environmental Management Report on an Environmental Management System for the North-West Province (North-West University Potchefstroom Campus 2004)

Claassen and Milton Land-use Planning 716 Claassen PE and Milton JRL "Land-use Planning" in Fuggle RF and Rabie MA (eds) Environmental Management in South Africa (Juta Kenwyn 1992) 716

Crowther (ed) Oxford Advanced Learner's Dictionary 219, 257

Crowther J (ed) Oxford Advanced Learner's Dictionary $5^{\text {th }}$ ed (Oxford University Press Oxford 1997) 219, 257

DEAT and DWAF National Waste Management Strategies

Department of Environmental Affairs and Tourism and Department of Water Affairs and Forestry National Waste Management Strategies and Action Plans South Africa: Action Plan Development Phase June 1999

Du Plessis "Legal Mechanisms" 1-23

Du Plessis W "Legal Mechanisms for Co-operative Governance in South Africa: Successes and Failures" (Unpublished paper delivered at the Berlin Conference on the Human Dimension of Global Environmental Change 3-4 December 2004 Berlin Germany) 1-23

Du Plessis Energy Law 103

Du Plessis W "Energy Law and Environmental Protection in South Africa" in Brebbia CA and Sakellaris I (eds) Energy and the Environment (WIT Press Southampton Boston 2003) 103 
Du Plessis 1995 SAJELP 23-36

Du Plessis W "Integration of Existing Environmental Legislation in the Provinces" 1995 South African Journal of Environmental Law and Policy 23-36

Du Plessis South Africa 29-121

Du Plessis W "South Africa" in Blanpain R (ed) International Encyclopaedia of Laws: Energy Law-Supplement 3 (Kluwer Law International The Hague 2001) 29-121

Du Plessis and Nel 2001 8(1) SAJELP 2

Du Plessis W and Nel JG "An Evaluation of NEMA Based on a Generic Framework for Environmental Framework Legislation" 2001 South African Journal of Environmental Law and Policy 8(1) 2

Glazewski Environmental Law 184-190

Glazewski J Environmental Law in South Africa $2^{\text {nd }}$ ed (LexisNexis Butterworths Durban 2005)

Kidd 1995 2(1) SAJELP 37-54

Kidd M "Integrated Pollution Control in South Africa: How Easy a Task?" 1995 2(1) South African Journal of Environmental Law and Policy 37-54

Kotzé "Co-operative Environmental Governance" 168

Kotzé LJ "Co-operative Environmental Governance: Towards the Establishment of an Integrated Authorisation System in the North-West Province" in IAIA Conference Proceedings: Co-operative Governance in Southern Africa: The Search for the Holy Grail International Association for Impact Assessment 17-20 June 2003 Marakech Morocco 168

Kotzé "Fragmented and Unsustainable Environmental Governance" Kotzé LJ "Addressing Fragmented and Unsustainable Environmental Governance in South Africa: Integrated Pollution Prevention and Control as 
a Framework for Integration Reforms" (Paper presented to the Ecopolitics XVI Conference 4-6 July 2005 Griffith University Brisbane Australia).

Kotzé Legal Framework 2-335

Kotzé LJ A Legal Framework for Integrated Environmental Governance in South Africa and the North West Province (Unpublished LLD thesis North West University Potchefstroom Campus 2005)

Kotzé Strategies 2, 5-6

Kotzé LJ "Strategies for Integrated Environmental Governance in South Africa: Towards a More Sustainable Environmental Governance and Landuse Regime" in Chalifour N et al (eds) Sustainable Land Use Volume Two of the Annals of the IUCN Academy of Environmental Law (To appear winter 2006) 2, 5-6

Kotzé and Du Plessis "International Environmental Law" 17-19

Kotzé LJ and Du Plessis AA "The Inception and Role of International Environmental Law in Domestic Biodiversity Protection Efforts: The South African Experience" (Unpublished paper delivered at the Biodiversity Conservation: Law and Livelihoods - Bridging the North South Divide Annual IUCN International Conference Macquarie University Sydney Australia July 2005) 17-19

Kotzé and Feris South Africa 39-44

Kotzé LJ and Feris L "South Africa" in Van der Linde M (ed) Environmental Law in Southern Africa (Juta To Appear Winter 2006) 39-44

Lawrence 1999 9(1) SAJELP 62

Lawrence R "How Manageable is South Africa's New Framework of Environmental Management?" 1999 9(1) South African Journal of Environmental Law and Policy 62

Meijers and Stead "Policy Integration" 3

Meijers E and Stead D "Policy Integration: What does it mean and how can 
it be Achieved? A Multi-disciplinary Review" (Unpublished paper delivered at the Berlin Conference on the Human Dimension of Global Environmental Change 3-4 December 2004 Berlin Germany) 3

Nel, Kotzé and Snyman "Strategies" 3-14

Nel JG, Kotzé LJ and Snyman E "Strategies to Integrate Environmental Policy at the Operational Level: Towards an Integrated Framework for Environmental Authorisations" (Unpublished paper delivered at the Berlin Conference on the Human Dimension of Global Environmental Change 3-4 December 2004 Berlin Germany) 3

Reddy 2001 20(1) Politeia 21-39

Reddy PS "Intergovernmental Relations in South Africa" 2001 20(1) Politeia 21-39

Scheepers Practical Guide 240

Scheepers T A Practical Guide to Law and Development: An Introduction to the Law Applicable to Development and the Development Management Process in South Africa (Juta Cape Town 2000) 240

Sharkansky Public Administration 32

Sharkansky I Public Administration: Policy-making in Government Agencies $2^{\text {nd }}$ ed (Markham Publishing Company Chicago 1972) 32

SPG Counting the Cost

Strategic Partnerships for Growth in Africa Counting the Cost of Red Tape in South Africa (SPB Johannesburg 2005)

Stein 1997 (4) SAJELP 254-268

Stein R "Regulation of Waste Management in South Africa: A Case for Integration" 1997 (4) South African Journal of Environmental Law and Policy 254-268 
Theunissen Administering National Government 12

Theunissen CA "Administering National Government" in Venter A (ed)

Government and Politics in the New South Africa $2^{\text {nd }}$ ed (Van Schaik

Publishers Pretoria 2003) 127

Wessels Environmental Authorisations

Wessels JA Environmental Authorisations and Mining Organisations (M Sc

Environmental Management North-West University, Potchefstroom

Campus 2005)

\section{Register of legislation}

Advertising on Roads and Ribbon Development Act 21 of 1940

Agricultural Pests Act 36 of 1983

Animal Improvement Act 62 of 1998

Animal Protection Act 71 of 1962

Atmospheric Pollution Prevention Act 45 of 1965

Aviation Act 74 of 1962

Criminal Procedure Act 51 of 1977

Communal Property Associations Act 28 of 1996

Conservation of Agricultural Resources Act 43 of 1983

Constitution of the Republic of South Africa 1996

Cultural Institutions Act 119 of 1998

Designated Areas Development Act 87 of 1979

Development Facilitation Act 67 of 1995

Dumping at Sea Control Act 73 of 1980

Electricity Act 41 of 1987

Environment Conservation Act 73 of 1989

Extension of Security of Tenure Act 62 of 1997

Fertilizers, Farm Feeds, Agricultural Remedies and Stock Remedies Act 36 of 1947

Foodstuffs, Cosmetics and Disinfectants Act 54 of 1972

Genetically Modified Organisms Act 15 of 1997

GN R898 Government Gazette 28016 of 9 September 2005

Hazardous Substances Act 15 of 1973 
Health Act 63 of 1977

Income Tax Act 58 of 1962

Inter-governmental Relations Framework Act 13 of 2005

Interim Protection of Informal Land Rights Act 31 of 1996

International Health Regulations Act 28 of 1974

Land Reform (Labour Tenants) Act 3 of 1996

Less Formal Township Establishment Act 113 of 1991

Limpopo Environmental Management Act 7 of 2003

Local Government Transition Act 209 of 1993

Local Government: Municipal Demarcation Act 27 of 1998

Local Government: Municipal Structures Act 117 of 1998

Local Government: Municipal Systems Act 32 of 2000

Management of State Forests Act 128 of 1992

Marine Living Resources Act 18 of 1998

Marine Pollution (Control and Civil Liability) Act 6 of 1981

Maritime Zones Act 15 of 1994

Mine Health and Safety Act 29 of 1996

Mineral and Petroleum Resources Development Act 28 of 2002

Mpumalanga Nature Conservation Act 10 of 1998

National Building Regulations and Building Standards Act 103 of 1977

National Environmental Management Act 107 of 1998

National Environmental Management: Air Quality Act 39 of 2004

National Environmental Management: Biodiversity Act 10 of 2004

National Environmental Management: Protected Areas Act 57 of 2003

National Environmental Management Amendment Act 8 of 2004

National Forests Act 84 of 1998

National Heritage Council Act 11 of 1999

National Heritage Resources Act 25 of 1999

National Monuments Act 28 of 1969

National Nuclear Regulator Act 47 of 1999

National Parks Act 57 of 1976

National Veld and Forest Fire Act 101 of 1998

National Road Traffic Act 93 of 1996

National Water Act 36 of 1998 
Nature and Environmental Conservation Ordinance 19 of 1974

Nature Conservation Ordinance 12 of 1983

Nature Conservation Ordinance 8 of 1969

Nuclear Energy Act 46 of 1999

Nuclear Energy Act 131 of 1993

Nuclear Regulator Act 47 of 1999

Occupational Health and Safety Act 85 of 1993

Petroleum Products Act 120 of 1977

Plant Breeder's Rights Act 15 of 1976

Plant Improvement Act 53 of 1976

Physical Planning Act 125 of 1991

Prevention of Illegal Eviction and Unlawful Occupation of Land Act 19 of 1998

Restitution of Land Rights Act 22 of 1994

Sea Birds and Seals Protection Act 46 of 1973

Sea Shore Act 21 of 1935

Stock Remedies Act 36 of 1947

Subdivision of Agricultural Land Act 70 of 1970

Upgrading of Land Tenure Rights Act 122 of 1991

Water Services Act 108 of 1997

Western Cape Nature Conservation Laws Amendment Act 2000

White Paper on Integrated Pollution and Waste Management 2000

White Paper on Integrated Pollution and Waste Management for South Africa:

A Policy on Pollution Prevention, Waste Minimisation, Impact Control and Remediation 2000

Wreck and Salvage Act 94 of 1996

\section{Register of cases}

Camps Bay Ratepayers and Residents Association and Others $v$ The Minister of Planning, Culture and Administration (Western Cape) and Others 20014 SA 301 (CPD)

Fedsure Life Assurance v Greater Johannesburg Transitional Metropolitan Council 199812 BCLR 1458 (CC) 